Article

\title{
Serbian Agriculture Policy: Economic Analysis Using the PSE Approach
}

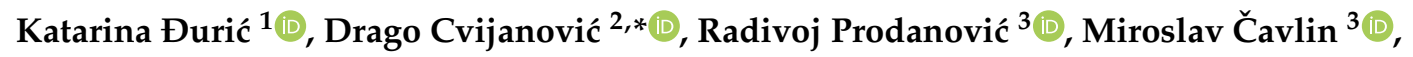 \\ Boris Kuzman $^{4}$ (D) and Mirjana Lukač Bulatović ${ }^{1}$ (D) \\ 1 Faculty of Agriculture, University of Novi Sad, Trg Dositeja Obradovića 8, 21000 Novi Sad, Serbia; \\ katarina.djuric@polj.uns.ac.rs (K.Đ.); lmirjana@polj.uns.ac.rs (M.L.B.) \\ 2 Faculty of Hotel Management and Tourism, University of Kragujevac, Vojvodjanska bb, \\ 36210 Vrnjacka Banja, Serbia \\ 3 Faculty of Economics and Engineering Management, University Business Academy, Cvećarska 2, \\ 21000 Novi Sad, Serbia; rprodanovic@fimek.edu.rs (R.P.); cmiros@gmail.com (M.Č.) \\ 4 Institute of Agricultural Economics, Volgina 15, 11000 Belgrade, Serbia; kuzmanboris@yahoo.com \\ * Correspondence: drago.cvijanovic@kg.ac.rs; Tel.: +381-36-515-0024
}

Received: 4 December 2018; Accepted: 4 January 2019; Published: 9 January 2019

\begin{abstract}
The purpose of the research is to identify the level of Government support to farmers' income in the Republic of Serbia. This support is based on market measures and budgetary transfers directed towards producers. As budgetary transfers are defined in the agricultural policy, by applying the producer support estimate (PSE) methodology, it is indirectly evaluated whether agricultural policies have a positive or negative impact on farmers' income and their economic status and the economic sustainability of farms. Producers of more significant agricultural commodities covered by the analysis in the period between 2012 and 2016 did not get any significant support from the state. Namely, most of the analyzed commodities had negative values of single commodity transfer (SCT) indicators, which means that agricultural producers received more taxes than incentives. In addition to the modest budgetary transfers, variations in their forms further negatively affect producers' income. Low share of budgetary transfers in the support structure to farmers leads to the conclusion that the support to farmers' income through higher prices on the domestic market is paid by consumers.
\end{abstract}

Keywords: agricultural policy; PSE Approach; Single Commodity Transfers; agricultural commodities; Serbia

\section{Introduction}

The process of socio-economic transition in the Republic of Serbia and transfer to the market economy model officially started in 1990 with the adoption of the Law on Privatisation. However, extensive social, economic and institutional reforms within the transition process did not start until 2000. These reforms resulted in a change of conditions in which the agricultural sector operated. There were also some changes in the field of agricultural policy [1]. The privatization of large state-owned agricultural production cooperatives, land policy reforms, market and price liberalization, establishing new institutions, and other changes accompanying the transition process, directly affected the economic situation of agricultural holders in the Republic of Serbia.

The importance of agriculture in the Republic of Serbia is clearly seen from its share in GDP generation, share in total employment, and many other indicators. Nevertheless, so far, no economic analysis of the agricultural policy indicating its effects on farmers' income has been carried out in the Republic of Serbia. 
The effects of economic policy on income in the agricultural sector can be achieved directly and indirectly. Directly, based on input and output, the level of interest rates, or salaries in agriculture, whereas the indirect effect is reflected in setting up efficient institutions [2].

According to the Organisation for Economic Co-operation and Development (OECD) criteria for defining rural areas, $85 \%$ of the Republic of Serbia can be classified as rural regions. Furthermore, almost half of the total population lives in these regions, while the average population density is 63 inhabitants per square kilometer. Two thirds of the rural area population are employed in agriculture as a main source of income. Furthermore, $85 \%$ of the total agricultural land is cultivated by family households. Agriculture is characterized by low productivity, unfavorable ownership structure (only $5.5 \%$ of agricultural households own more than 10 ha of land), outdated technology, limited investment resources, and rural areas have a low degree of diversification of rural economy [3].

The purpose of the research is to identify the level of Government support to the farmers' income in the Republic of Serbia. This support is based on market measures and budgetary transfers directed towards producers. As budgetary transfers are defined in the agricultural policy, by applying the producer support estimate (PSE) methodology, it is indirectly evaluated whether agricultural policies have a positive or negative impact on farmers' income and their economic status and the economic sustainability of farms.

The initial hypothesis is: producers of the commodities which are the subject of the analysis were deprived of the support provided through agricultural subsidies.

The scientific contribution of the paper is the analysis of Government support to agriculture in the Republic of Serbia. The contribution of the paper is quantifying the impact of market (pricing) and budgetary measures on the farmers' income, thus pointing to the need to improve incentives in order to achieve economic sustainability of agricultural households. The share of smallholder family farms in the agricultural structure of Serbia is very high, but without proper incentives and budgetary transfers, their economic survival and economic and social sustainability are under threat.

\section{Main Features of Agriculture in the Republic of Serbia}

The Republic of Serbia belongs to a group of former socialist countries whose economy, including the agricultural sector, is undergoing the transition process, that is, transformation from centrally planned economy to market economy. The decrease in production and real income, together with the unemployment rate increase, as side effects of the transition process, were particularly visible in the agriculture and food industry. In 2012, the Republic of Serbia was granted EU candidate country status, which brought about new challenges for agricultural and agrarian policy.

With an average GDP per capita of 5770 USD in the period between 2012 and 2016, the Republic of Serbia was seriously lagging behind EU countries (Table 1). Real GDP growth rates ranged from $-1 \%$ in 2012 up to $2.8 \%$ in 2016. Agriculture plays a prominent role in the economic structure of the Republic of Serbia. Namely, in the observed five-year period, agriculture and food industry accounted for $23 \%$ of the total GDP (Table 1). Good fertility control of agricultural land and favorable natural conditions resulted in a high share of GDP from agriculture in the total gross value added in the Republic of Serbia. In addition, slow agricultural reforms and development of the secondary and tertiary sectors led to a high share of the agricultural sector in all macroeconomic aggregates [4]. Consequently, GDP in rural regions of the Republic of Serbia accounted for $74 \%$ of the national average and, according to estimates, around one million people living in this region face poverty [3]. The contribution of agriculture of $19.3 \%$ of total employment also speaks in favor of the fact that this field of the economy accounts for a very significant part of the working population [5].

In addition to rural population dominance, the availability of natural resources, primarily land resources, speaks in favor of the important role of agriculture in the economic structure of the Republic of Serbia. However, although availability of agricultural land is relatively high and accounts for 0.7 ha per capita, this natural resource has not been rationally used. The average size of an agricultural household in the Republic of Serbia is only 5.44 ha, which indicates an extremely unfavorable 
ownership structure and negatively affects productivity and competition in the field of agricultural production (Table 1). From the aspect of available agricultural land, with regards number of livestock units and achieved production values, smallholder farms prevail in the agricultural structure [1]. The majority of agricultural land is owned by individual agricultural households, while only part of agricultural production is carried out by companies. A low level of agricultural development and productivity can also be seen from the data on the yield of the most important commodities. The average wheat yield in the period between 2012 and 2016 was 4.3 ha, while milk production totaled 3380 liters per cow (Table 1). In addition, significant yield fluctuations can be noticed depending on weather conditions, which indicate low production intensity [5].

As for the foreign agricultural trade, in 2005, the Republic of Serbia started achieving a surplus, with an average of 357 million USD per annum. Moreover, the Republic of Serbia is a leading producer of agricultural and food products and the only net food exporter in the Western Balkans region [6]. In the period between 2004 and 2014, the Republic of Serbia saw a surplus of 3.1 billion EUR from agricultural commodity trading [7]. However, agricultural export in Serbia is dominated by primary agricultural commodities, while highly processed products are exported, which is not a very favorable position.

Table 1. Importance of agriculture in the economic structure of the Republic of Serbia.

\begin{tabular}{lc}
\hline & Average for the Period 2012-2016 \\
\hline GDP per capita (USD/inhabitant) & 5770 \\
Share of GVA from agriculture and food industry in total GDP (\%) & 23 \\
Share of GVA in agriculture and food industry in total GDP (\%) & 6.3 \\
Share of agriculture in employment (\%) & 19.3 \\
Share of rural population in total population (\%) & 49.6 \\
Wheat yield (t/ha) & 4.3 \\
Milk production (L/cow) & 3380 \\
Agriculture land per capita (ha) & $0.7 \mathrm{al}^{1}$ \\
Average size of agricultural holding (in ha) & $0.46 \mathrm{ual}^{2}$ \\
Agricultural trade balance (mil. USD) & 5.44 \\
\hline${ }^{1}$ agricultural land; ${ }^{2}$ used agricultural land; Source: authors calculation based on Statistical Office of the Republic of \\
Serbia [5]. & +357 \\
\end{tabular}

One of the main restrictions in agricultural development in the Republic of Serbia is the lack of consistent agricultural policy and strategy, which would lead to changes and compliance with the EU Common Agricultural Policy (CAP). Instead, there is a pragmatical 'ad hoc' approach to problem solving [8]. Absence of clear strategy and priorities in the field of agricultural policy greatly restrict competition within the agricultural sector, long-term sustainable development, and the welfare of the rural population. One of the most significant features of agricultural policy in the Republic of Serbia is an unpredictable and unstable budget framework. As a result, distribution of funds for individual purposes changes from year to year [9]. Prominent variability in the structure and amount of budgetary transfers to agriculture is caused by changes in the entire national budget, which are the consequence of political and economic instability [10].

Despite the low level of development of agriculture in the Republic of Serbia, it represents an important economic activity. Its role is to ensure the country's food security, produce raw material for non-agricultural activities, and provide products for export. In addition, due to a long history and dominance of the rural areas, this activity in the Republic of Serbia is both socially and demographically significant.

\section{Agricultural Budget Structure in the Republic of Serbia}

The agricultural budget is a safe and permanent source of agrarian funding. It has been designed as a unified support provided by the state to agriculture for the maintenance of current production, but it is also aimed at fostering development of this strategically important activity [11]. 
The Law on Incentives in Agriculture and Rural Development and the Budget System Law of the Republic of Serbia for 2016 stipulate the amount of funds, types, and maximum amount according to types of subsidies in agriculture and rural development. The agricultural budget funds have been distributed among the following four program activities: direct payments, rural development measures, credit support to agriculture, and special incentives [12]. The Republic of Serbia, as an EU candidate country, introduced a "CAP-like" agrarian policy in 2016 (shown in Tables 2 and 3).

In the total budget funds allocated to agriculture in 2016, direct payments had the greatest share of $87 \%$ (Table 2). Rural development measures accounted for $9 \%$ of the total agricultural budget, whereas credit support participated with $3 \%$ and special incentives with only $1 \%$.

Table 2. Participation of certain activities in the agricultural budget of the Republic of Serbia in 2016.

\begin{tabular}{lc}
\hline \multicolumn{1}{c}{ Program Activity/Project } & Share in Agricultural Budget (\%) \\
\hline Direct payments & 87 \\
Rural development measures & 9 \\
Credit support & 3 \\
Special incentives & 1 \\
\hline Total & 100 \\
\hline \multicolumn{2}{c}{ Source: [12]. }
\end{tabular}

Recently, direct support measures have become the main element of budgetary transfers in agriculture in the Western Balkans. This kind of support is also becoming the key factor of agrarian budget growth [13]. Direct support to farmers in the Republic of Serbia has been realized as: direct payments based on output, payments per hectare and animal, and input subsidies. An average of $70 \%$ of agricultural budget is used for these three types of transfer [1].

The program activity "direct payments" includes subsidies aimed at agricultural production. Direct support was introduced based on the EU Common Agricultural Policy and comprises incentives for plant and livestock production (Table 3). However, direct payments do not deal with meeting environmental protection criteria, as is the case with the Common Agricultural Policy. Such form of budget support is suitable only for producers, but it does not lead to the implementation of European standards and higher competitiveness of the agricultural sector of the Republic of Serbia. Reluctance of the agrarian policy makers to fully comply with the CAP calls into question the efficiency of measures that take up most of the agricultural budget.

Table 3. Participation of certain types of subsidies in direct payments for agriculture in the Republic of Serbia in 2016.

\begin{tabular}{lc}
\hline \multicolumn{1}{c}{ Type of Incentives } & Share (\%) \\
\hline Premiums for milk & 20.02 \\
Basic incentives for plant production & 20.78 \\
Incentives for quality breeding dairy cows, breeding beef cows, breeding sheep and goats, sows, & 30.98 \\
parent chickens light and heavy type, parent turkeys, quality breeding parent carp and trout & 5.30 \\
Incentives for fattening beef cows, lambs, kids, pigs & 0.12 \\
Incentives for suckler cows & 1.89 \\
Incentives for beehives & 0.17 \\
Incentives for fish production & 20.78 \\
Price reductions for fertilizers & 0.01 \\
Price reductions for storage costs & 100 \\
Total & \\
\hline
\end{tabular}

Source: [12].

Rural development in the Republic of Serbia has been defined as one of the key economic priorities. Diversification of the rural economy through environmental, economic, and social sustainability should lead to an improvement in the quality of life of the local rural population and to poverty reduction [14]. 
Whereas the support within direct payments is directed primarily to the improvement of agricultural production as a key economic activity in rural regions, rural development measures are focused on providing financial and technical support, which will lead to better living and working conditions in rural areas (Table 4).

Table 4. The structure of rural development incentives in the Republic of Serbia in 2016.

\begin{tabular}{lc}
\hline \multicolumn{1}{c}{ Type of Subsidy } & Share (in \%) \\
\hline Investments in agricultural production for the improvement of & 65 \\
competitiveness and achieving high quality standards & 8 \\
Incentives for sustainable rural development & 2 \\
Incentives for improvement of rural economy & 19 \\
Incentives for the support of advisory and expert services in agriculture & 3 \\
Funds for participation in funding of IPARD ${ }^{1}$ measures & 100 \\
Total &
\end{tabular}

"Special incentives" activity comprises incentives for implementing livestock breeding programs aimed at achieving goals in the field of animal husbandry, as well as incentives for implementing scientific and research development and innovative projects in agriculture.

Although the number of commercial households is increasing, small family farmers still play an important role in the agricultural sector of all Western Balkan countries and the Republic of Serbia is no exception to that [8]. It has been estimated that budget support is of the utmost importance to poor producers in rural areas who have less favorable working conditions, primarily due to their unfavorable economic position but also because of the lack of affordable loans [15].

Small family farms represent an irreplaceable part of the rural economy and hence it is necessary to pay special attention to them, both through rural development policy measures and through direct budget incentives aimed at production [4]. Furthermore, the important role of small family farms in the employment of the rural population, production stability and food self-sufficiency, preservation of rural traditional values, and balanced territorial development should not be neglected.

In recent years, reforms in national agricultural policy have been focused on compliance with the EU Common Agricultural Policy. Consequently, this should lead to an increase in budgetary transfers to agricultural producers [11]. Having in mind the existing relatively low level of support to domestic producers, key changes in this field should refer to setting up more efficient support mechanisms in agriculture. The important thing for the Republic of Serbia in the years prior to the end of EU accession negotiations, as far as the agricultural sector is concerned, is making use of subsidy systems for creating incentives for farmers with the intention of increasing production volume as much as possible. Namely, once a country enters the European Union, subsidization on the basis of realized production shall no longer be applied. Therefore, it seems logical to make the best of current production potentials in the years prior to full compliance with the Common Agricultural Policy measures. In order to meet this goal, it is necessary to improve the institutional framework, primarily, increase the agricultural budget in its absolute amount, as well as to provide other realistic and, for producers, affordable funding sources. The increase in the budget allocated for agriculture and rural development presents an important prerequisite for efficient integration into the system of the EU Common Agricultural Policy, since, according to the present EU agricultural policy for the period 2014-2020, new member states are allowed to additionally finance a part of the measures from Pillar 1 from their own resources [16].

\section{Materials and Methods}

Producer support estimate (PSE) methodology, created by the OECD, was used to calculate the volume of support to basic agricultural commodities [17]. This methodology was first applied at the end of the 1980s and has been improved since. PSE presents an annual monetary value of gross 
transfers from consumers and taxpayers to agricultural producers, measured at the farm-gate level, arising from agricultural policy measures, regardless of their nature, and objectives and impacts on farm production or income. PSE methodology does not calculate the impact of agricultural policy measures on agriculture but provides information that can be quantified to illustrate that impact. If, for example, a PSE for a certain commodity is assumed to be zero, it means that producers sell their commodities on the domestic market at world commodity prices and receive no support whatsoever from the state. If PSE is positive, it means that producers are subsidized either through prices support and/or through various budgetary payments. However, if PSE indicator is negative, it means that producers are taxed either based on lower prices as compared to the world commodity prices and/or based on taxes imposed by agricultural or trade policy measures.

This methodology is not free of significant defects. The approach, based on the concept of economic surplus, is criticized primarily on the grounds of the excessive restrictiveness of the assumptions adopted, and, in particular, the assumption that conditions of perfect competition exist everywhere and the ignoring of transaction costs resulting from changes in other markets for products or production factors when considering transformation in a given market [18].

The PSE framework implies the calculation of a large number of indicators for measuring producer support. Namely, PSE can be divided into four components, that is, calculated on four different levels [17]:

- $\quad$ Single commodities: Single Commodity Transfers (SCT)

- $\quad$ A group of commodities, e.g., cereals: Group Commodity Transfers (GCT)

- $\quad$ All agricultural commodities: All Commodity Transfers (ACT)

- Transfers provided without obligation on the part of recipients to produce commodities: Other Transfers to Producers (OTP)

This paper uses producer Single Commodity Transfers (SCT), or its relative expression \% SCT for individual commodities, which account for $70 \%$ of the total value of agricultural production in the Republic of Serbia. SCT is basically the same indicator as the \% PSE because it takes into account the same elements of calculation. It is a useful economic indicator for planning future budget support for agriculture, including further investment in infrastructure and strengthening of general services in agriculture [19].

Producer Single Commodity Transfers (producer SCT) is the annual monetary value of gross transfers from consumers and taxpayers to agricultural producers, measured at the farm gate level, arising from policies linked to the production of a single commodity such that the producer must produce the designated commodity in order to receive the transfer [17]. Single Commodity Transfers can be derived for individual commodities and at the national level. Most frequently it is represented as a percentage value, so called percentage SCT. It is expressed with the following mathematical equation:

Producer SCT $=$ MPS $+\Sigma$ BOT

where:

MPS-market price support

$\Sigma$ BOT—national aggregate budgetary and other transfers to producers from policies that have been labelled as based on a single commodity (SC)

MPS component is calculated as a Price Gap Calculation, i.e., MPD—Market Price Differential. The MPD for a commodity estimated using this method is expressed as:

$$
\mathrm{MPD}=\mathrm{PP}-\mathrm{RP}
$$

and:

$$
\mathrm{RP}=(\mathrm{BP} \times \mathrm{QA}-\mathrm{MM}) \times \mathrm{WA}
$$


where:

$\mathrm{PP}$ - producer price

$\mathrm{RP}$ — reference price (border price at farm gate)

$\mathrm{BP}-$ border price of commodity of products derived from commodity

QA-quality adjustment co-efficient for commodity

MM-marketing margin adjustment for commodity

WA-weight adjustment co-efficient for commodity

BOT—budgetary and other transfers to producers, as the second component of the PSE indicator can occur in different forms. Most common forms are payments based on output, input use, current production required, and non-current production required.

Percentage SCT presents the share of gross producer receipts arising from agricultural policy measures. This relative indicator is calculated in the following way:

$$
\% \mathrm{SCT}=\text { producer } \mathrm{SCT} / \mathrm{GR} \times 100
$$

and:

$$
\mathrm{GR}=\mathrm{VP}+\text { producer } \mathrm{SCT}-\mathrm{MPS}
$$

where:

$\%$ SCT-percentage SCT

GR-gross receipts for that commodity

$\mathrm{VP}$-market receipts

Since relevant data on price and budgetary support to agriculture for the Republic of Serbia are still not inserted in the OECD database, various data sources are used for determining the volume of support for basic agricultural commodities in the Republic of Serbia. The Statistical Office of the Republic of Serbia is used as a primary source of information on domestic commodity prices. The second element of price differential calculation, that is, world or reference price for the commodities included in the analysis, has been established based on data published by the Food and Agriculture Organization (FAO) in their regular publications. The analysis also comprises all data on world prices of agricultural commodities available on the official website of this organization, from the FAOSTAT statistical database.

Reference prices expressed in USD are converted to RSD according to the official exchange rate of the National Bank of Serbia (based on average monthly, that is, annual exchange rate) for corresponding years, published by the National Bank on their website.

Data on budgetary allocations allocated by the state to various forms of subsidies of agricultural producers in the Republic of Serbia are published in the Official Gazette of the Republic of Serbia as a part of the Law on the Budget. This publication has been used as a source of data on the level of various budgetary transfers, which, together with the price differential calculation, present an integral part of the support to domestic farmer incomes [20].

\section{Results and Discussion}

\section{Indicators of Support to Individual Agricultural Commodities}

The selection of agricultural commodities to be analyzed is made according to criteria stipulated by the OECD. Namely, according to the OECD methodology, the calculation of the support using the PSE approach is by rule carried out only for agricultural commodities that account for $70 \%$ of the total value of agricultural output in a given country in the observed period. In the Republic of Serbia, in the period between 2012 and 2016, the following six commodities accounted for the biggest share: wheat, corn, soybean, sunflower, beef, and pork. These commodities represent $70 \%$ of the total agricultural output in the agriculture of the Republic of Serbia, and according to the OECD definition, they are 
referred to as market price support (MPS) commodities. The SCT indicator was calculated for the above-mentioned commodities for the period between 2012 and 2016 (Table 5; Figure 1).

Table 5. Calculation of \% SCT for individual commodities (2012-2016).

\begin{tabular}{cccccccc}
\hline & Units & Wheat & Corn & Sunflower & Soybean & Beef & Pork \\
\hline Value of production & Mil RSD & 16.02 & 39.49 & 4.35 & 3.78 & 6.45 & 20.31 \\
\hline $\begin{array}{c}\text { Producer Single Commodity } \\
\text { Transfers (producer SCT) }\end{array}$ & Mil RSD & -2.01 & 6.41 & -1.27 & 0.46 & -6.84 & -12.09 \\
\hline A1. Market Price Support (MPS) & Mil RSD & -2.01 & 6.41 & -1.98 & -0.13 & -6.84 & -12.09 \\
\hline A2. Payments based on output & Mil RSD & 0.00 & 0.00 & 0.00 & 0.00 & 0.00 & 0.00 \\
\hline B. Payments based on input use & Mil RSD & 0.00 & 0.00 & 0.71 & 0.58 & 0.00 & 0.00 \\
\hline $\begin{array}{c}\text { C2. Payments based on current } \\
\text { A/An, production required } \\
\text { (single payment) }\end{array}$ & Mil RSD & 0.00 & 0.00 & 0.00 & 0.00 & 0.00 & 0.00 \\
\hline $\begin{array}{c}\text { D. Payments based on } \\
\text { non-current A/An/R/I, } \\
\text { production required (single } \\
\text { commodity) }\end{array}$ & Mil RSD & 0.00 & 0.00 & 0.00 & 0.00 & 0.00 & 0.00 \\
\hline $\begin{array}{c}\text { Gross receipts for individual } \\
\text { commodity }\end{array}$ & Mil RSD & 16.02 & 39.49 & 5.06 & 4.32 & 6.45 & 20.31 \\
\hline $\begin{array}{c}\text { Percentage Producer Single } \\
\text { Commodity Transfer }\end{array}$ & $\%$ & -0.13 & 0.16 & -0.34 & 0.06 & -1.03 & -0.61 \\
\hline$\quad$ Somrce auth & & & & & & \\
\hline
\end{tabular}

Source: authors calculation based on Statistical Office of the Republic of Serbia [5].

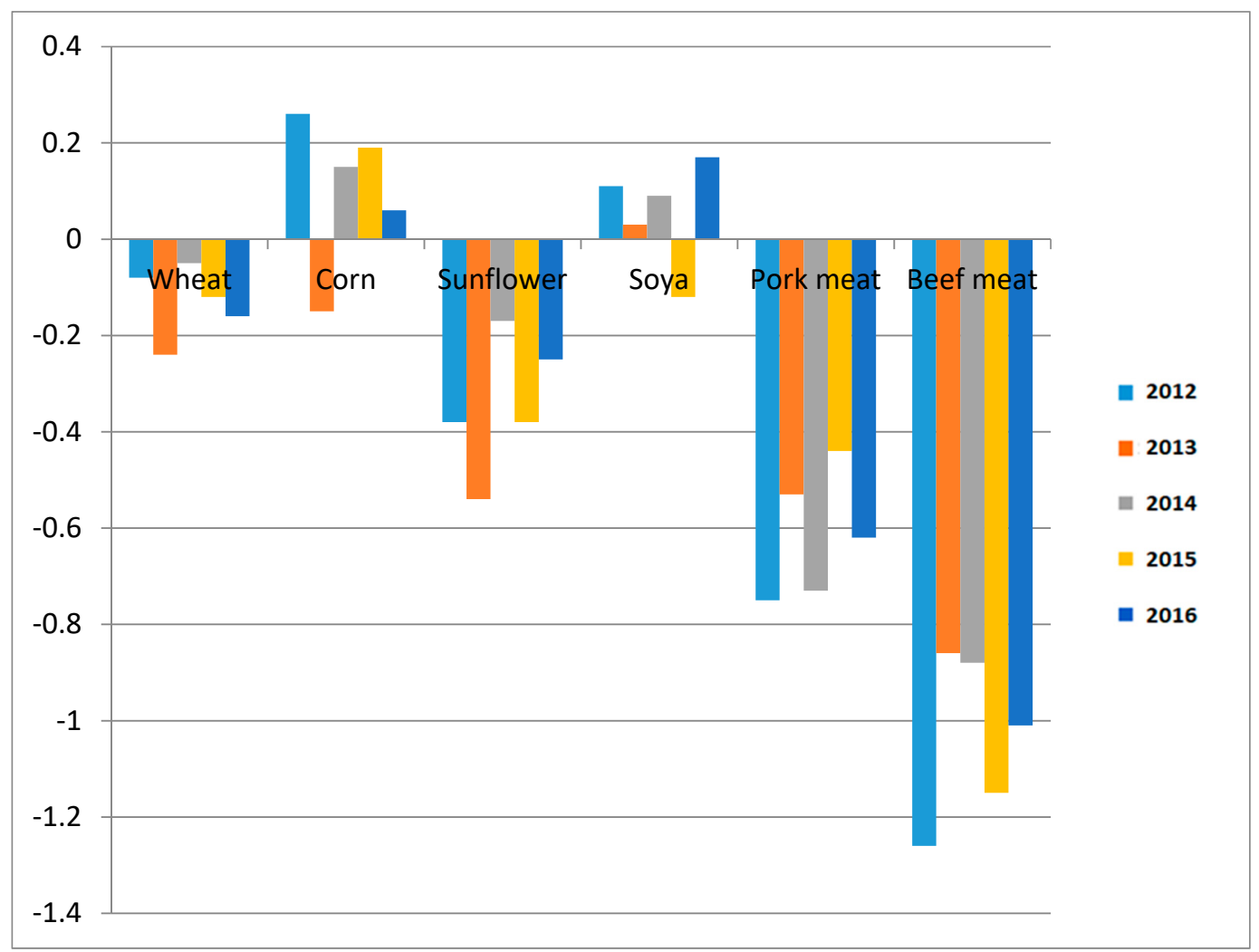

Figure 1. Single Commodity Transfers-SCT (in \%). Source: authors, based on Statistical Office of the Republic of Serbia [5].

The level of support for wheat producers' income, expressed by SCT indicator value, according to available data for the period between 2012 and 2016, is extremely low. The increase in the price of bread 
wheat on the domestic market was not always in line with price movements of the world commodity prices, which resulted in negative market price support (MPS). While wheat prices in the observed period in the Republic of Serbia increased by an average of $15.34 \%$ per annum, the overall growth rate of reference prices of this product was $33.86 \%$. In addition to the price movement fluctuations, the negative value of SCT was also caused by the absence of budget support to wheat producers in the Republic of Serbia in the period between 2012 and 2016.

Price support to corn producers was present throughout the entire observed period. Due to the absence of any kind of budgetary payments, the entire corn producer income support in the Republic of Serbia was based on corresponding pricing. However, despite the defined pricing policy, it could be said that the total level of support to domestic corn producers was relatively low. Furthermore, the corn price growth rate of $9.75 \%$ on the internal market was significantly falling behind world prices, whose growth rate in the analyzed period was $33.52 \%$.

During the first two analyzed years, there was no price support to sunflower producers. Due to the absence of budgetary transfers, this had an unfavorable effect on the total level of support to this commodity. Namely, in 2012 and 2013 the SCT was negative, which leads to the conclusion that there was no active support to sunflower producers. The introduction of premiums to sunflower producers did not result in positive values of SCT indicators, although the support to producers increased. Negative differences in the price of sunflower, in the last three years of the observed period, could not be overcome, not even by introducing budgetary premium payments.

The price protection of soybean producers present in the first two years of the analyzed period, resulted in positive values of the SCT indicator. The price growth of this commodity on the domestic market did not follow the growth trend on the international market, which led to a negative impact on the value of the first component of the SCT indicator. In 2015, in addition to positive price difference, the value of the SCT indicator also implies the presence of significant support to the soybean producers in the form of incentives from the budget of the Republic of Serbia. The price growth rate of soybean on the internal market was $9.18 \%$ in the observed period. However, the reference price rate was very prominent and amounts to $41.26 \%$. However, owing to the funds obtained from the agricultural budget and payments of premiums to soybean producers, the final level of support to this commodity in the observed period was relatively high. The comparison of SCT values of individual commodities clearly shows that soybean producers were among the few whose income during the entire analyzed period was supported to a certain extent, either through pricing support or through budgetary transfers.

In the period between 2012 and 2016, the MPS value of the SCT indicator for beef was negative. In addition, the absence of direct budgetary transfers caused extremely unfavorable conditions for beef producers in the Republic of Serbia. Analysis results of this commodity show the negative value of the SCT indicator during the entire period. The negative value of the market price support was partly caused by the prominent difference in the dynamics of growth rate of domestic and reference prices. Namely, according to available data in the period between 2012 and 2016, the change rate of 13.25\% expresses movement of prices of beef on the domestic market. In the same period, according to the $\mathrm{FAO}$, the increase rate of the price of beef on the global market was $32.86 \%$ over the five-year period.

From the point of budgetary transfers to producers, completely identical circumstances also apply to the production of pork in the Republic of Serbia. Domestic and reference price dynamics were also similar to changes recorded for prices of other analyzed agricultural commodities. The change rate of $25.68 \%$ illustrates a significantly more intensive increase of prices on the global market as compared to the internal market. Namely, the increase rate of domestic prices of pork in the observed period was $12.58 \%$ per annum.

In summary, producers of most commodities analyzed in the period between 2012 and 2016 in the Republic of Serbia were deprived of the most significant aspect of state support. Namely, most of the analyzed commodities had negative values of SCT indicators, which leads to the conclusion that agricultural producers were imposed with more taxes than they were offered incentives. 
The analysis of the structure of SCT indicators also confirms that the presence of budgetary transfers to agricultural producers in the Republic of Serbia is extremely modest. Low share of budgetary transfers in the structure of support to farmers points to the conclusion that the support for farmer incomes through higher prices on the domestic market is, in fact, paid by the consumers of agricultural and food products. The dominant form of budgetary transfers to producers are input subsidies, that is, transfers related to production volume, which is typical for developing countries. A similar structure of budgetary transfers is common for the majority of former socialist countries such as, Armenia, Moldova, Belarus, Azerbaijan, and the Ukraine [21,22]. As for input subsidies, the most important is the price reduction for diesel fuel and mineral fertilizers. In addition, in the mechanism of financial support to European agriculture, farmers' income is supported primarily through direct payments, with the entitlement to those transfers being linked increasingly to the fulfilment of conditions, particularly environmental ones [18].

\section{Conclusions}

Producers of basic agricultural commodities in the Republic of Serbia are deprived of the most significant form of support. Identified negative values of SCT indicators point to the conclusion that, due to a lack of direct and indirect budgetary payments, agricultural producers in the Republic of Serbia, in a way, pay more taxes than they get incentives. Moreover, apart from modest budgetary transfers, variations in their forms additionally negatively effect farmer incomes. There was a high level of heterogeneity in the types of subsidies in the agricultural subsidy system in the Republic of Serbia within the analyzed period. Budgetary transfers in the observed period were paid out according to the generated output and as a price reduction in diesel fuel, mineral fertilizers, and other inputs. One of the basic features of agrarian policy in Serbia is unpredictable and unstable budgetary framework, leading to the frequent change in the distribution of funds for different purposes. It was only recently that the Republic of Serbia, as an EU candidate country, introduced "CAP-like" agrarian policy. Budgetary transfer data used in the paper were obtained from the national database, that is, the Official Gazette of the Republic of Serbia, since the data for the Republic of Serbia have still not been recorded within the OECD database.

The level of support of domestic producer income is relatively low, hence it is necessary to introduce crucial changes in establishing more efficient mechanisms of support to agriculture.

A great number of factors can influence farmers' income and quantifying their impact goes beyond the PSE methodology approach. Nevertheless, this methodology has been applied in the paper with the purpose of quantifying the impact of pricing and budgetary support to producers of certain agricultural products.

The low level of support to agriculture has an unfavorable effect on farmers' income and the economic and social sustainability of agricultural households. The introduction of a "CAP-like" subsidy system should, in the period to come, provide more efficient protection of farmers' income and the distribution of subsidies on a greater number of products. Furthermore, consistent implementation of agricultural policy is a condition without which the long-term sustainable development of agriculture and rural areas in the Republic of Serbia is not possible.

This work should be concerning as a preliminary and as attempt to increase the knowledge about agricultural policy measures in the Republic of Serbia. A weak permanent monitoring system, the complexity of the issues and poor data availability limit the scope of our work. The authors are fully aware these results should be interpreted with caution.

Author Contributions: This paper is the result of a joint effort of all the authors. K.Đ. wrote the Results and Discussion and has drawn conclusions; D.C. explained the methodology of research and the PSE approach; R.P. wrote the Introduction and Abstract, designed the graphs and made technical and logical corrections; M.Č. and B.K. wrote Sections 2 and 3 on the importance of agriculture and the agricultural budget in the Republic of Serbia and they provided references; M.L.B. gave useful suggestions on the interpretation of the results and checked the English version of the paper. All authors agreed to submit the paper. 
Funding: This research received no external funding.

Acknowledgments: The paper represents a part of the research of the project III 46006-Sustainable agriculture and rural development in terms of the Republic of Serbia strategic goals realization within the Danube region, funded by the Ministry of Education, Science and Technological Development of the Republic of Serbia.

Conflicts of Interest: The authors declare no conflicts of interest.

\section{References}

1. Bogdanov, N.; Rodić, V. Agriculture and Agricultural Policy in Serbia. In Agricultural Policy and European Integration in Southeastern Europe; Volk, T., Erjavec, E., Mortensen, K., Eds.; Food and Agriculture Organization of the United Nations: Budapest, Hungary, 2014; pp. 153-171, ISBN 978-92-5-108612-4.

2. Lema, D.; Gallacher, M. Argentine Agricultural Policy: Economic Analysis and Impact Assessment Using the Producer Support Estimate (PSE) Approach, in Agriculture in an Interconnected World. In Proceedings of the 29th International Conference of Agricultural Economists-ICAE, Milan, Italy, 9-14 August 2015; International Association of Agricultural Economists (IAAE): Milwaukee, WI, USA, 2015.

3. Vujičić, M.; Ristić, L.; Vujičić, M. European integration and rural development policy of the Republic of Serbia and Western Balkan countries. Bulg. J. Agric. Sci. 2012, 18, 519-530.

4. Gajić, T.; Vujko, A.; Cvijanović, D.; Penić, M.; Gagić, S. The State of Agriculture and Rural Development in Serbia. R-Economy 2017, 3, 196-202. [CrossRef]

5. Statistical Office of the Republic of Serbia. Available online: http://www.stat.gov.rs/ (accessed on 17 May 2018).

6. Mizik, T. Western Balkans: State of Agriculture and its Opportunities on the Eve of EU Acccession. Acta Universitatis Danubius CEconomica 2011, 10, 30-52.

7. Stegić, M. Foreign trade in agri-food between Serbia and European Union. Ekonomija: Teorija i Praksa 2016, 9, 1-18. [CrossRef]

8. Volk, T.; Rednak, M.; Erjavec, E. Western Balkans agriculture and European integration: Unused potential and policy failures? Post-Communist Econ. 2012, 24, 111-123. [CrossRef]

9. Bogdanov, N.; Rodić, V.; Vittuari, M. Structural change and transition in the agricultural sector: Experience of Serbia. Communist Post-Communist Stud. 2017, 50, 319-330. [CrossRef]

10. Bajramović, N.; Bogdanov, N.; Butković, J.; Dimitrievski, D.; Erjavec, E.; Gjeci, G.; Gjokaj, E.; Hoxha, B.; Stomenkovska, I.J.; Konjević, D.; et al. Analysis of the Agricultural and Rural Development Policies of the Western Balkan Countries; Volk, T., Erjavec, E., Ciaian, P., Gomez, S.P., Eds.; Joint Research Centre, European Commission: Luxembourg, 2016; ISBN 978-92-79-58014-7, ISSN 1831-9424.

11. Kuzman, B.; Đurić, K.; Mitrović, L.J.; Prodanović, R. Agricultural Budget and Agriculture Development in Republic of Serbia. Econ. Agric. 2017, 64, 515-531. [CrossRef]

12. Đurić, K.; Vukoje, V.; Tomaš-Simin, M. Agrarni budžet kao oblik finansiranja poljoprivrede u Republici Srbiji i Hrvatskoj. Agroekonomika 2016, 45, 13-21.

13. Volk, T.; Rednak, M.; Emil, E.; Juvančič, L. Development of a tool for comparative analysis of agricultural and rural development policies measures and its application on Western Balkan countries. In Proceedings of the Triennial Conference, Foz do Iguaçu, Brazil, 18-24 August 2012; International Association of Agricultural Economists (IAAE): Milwaukee, WI, USA, 2012.

14. Petrović, D.; Vujko, A.; Gajić, T.; Vuković, D.; Radovanović, M.; Jovanović, J.; Vuković, N. Tourism as a Approach to Sustainable Rural Development in Post-Socialist Countries: A Comparative Study of Serbia and Slovenia. Sustainability 2018, 10, 54. [CrossRef]

15. Mizik, T. The Diversity of Agriculture in Former Soviet and Western Balkan Countries. Policy Stud. Rural Transit. 2010, 1-87.

16. Matthews, A.; Salvatrici, L.; Scoppola, M. Trade Impacts of Agricultural Support in the EU. Commissioned Paper No. 19. International Agricultural Trade Research Consortium, 2017. Available online: https://ageconsearch.umn.edu/bitstream/252767/2/IATRC\%20CP19\%20\%20Matthews\%20Salvatici\%20Scoppola.pdf (accessed on 26 May 2018).

17. OECD. Trade and Agriculture Directorate, OECD's Producer Support Estimate and Realted Indicators of Agricultural Support-Concepts, Calculations, Interpretation and Use, The PSE Manual; OECD: Paris, France, 2008. 
18. Kulyk, P.; Czyzewski, B. Disproportions in the system of support for agriculture in EU countries: An attempt at estimation. In Political Rents of European Farmers in the Sustainable Development Paradigm. International, National and Regional Perspective; Czyzewaki, B., Ed.; Polish Scientific Publishers (PWN): Warszawa, Poland, 2016; pp. 103-117, ISBN 978-83-01-18766-8.

19. Đurović, G.; Bulatović, B. Product support estimate (PSE) for the beef meat production in Montenegro. Industrija 2014, 42, 35-56. [CrossRef]

20. Službeni Glasnik Republike Srbije, 8/2016, Uredba o raspodeli podsticaja u poljoprivredi i ruralnom razvoju u 2016. godini. Available online: http://www.kombeg.org.rs/Slike/UdrPoljoprivreda/2016/februar/ uredba.pdf (accessed on 12 May 2018).

21. Erjavec, E.; Volk, T.; Rac, I.; Kožar, M.; Pintar, M.; Rednak, M. Agricultural support in selected Eastern European and Eurasian countries. Post-Communist Econ. 2017. [CrossRef]

22. Kožar, M.; Pintar, M.; Volk, T.; Rednak, M.; Rac, I.; Erjavec, E. Agriculture and agricultural policy in Eastern European Nieghbourhood. Present at the 155th EAAE Seminar “European Agriculture towards 2030 Perspectives for further East-West Integration", Kiev, Ukraine, 19-21 September 2016.

(C) 2019 by the authors. Licensee MDPI, Basel, Switzerland. This article is an open access article distributed under the terms and conditions of the Creative Commons Attribution (CC BY) license (http:/ / creativecommons.org/licenses/by/4.0/). 